\title{
Acknowledgments
}

\author{
Joseph Coleman Carter
}

The discovery of the Sanctuary began with the first excavation at Pantanello in the chora of Metaponto, 43 years ago, in June of 1974. There followed intensive campaigns of excavation-ten in the next decade alone, and a dozen in all-and years of study that reached important conclusions as recently as this year. These three volumes, by presenting the full and considered factual evidence, we hope, will stimulate further research. The excavation, analysis, and publication are the results of many years of intense effort and devoted study by a large number of talented people who worked together as a team over the course of four decades, supported financially and morally by a small but loyal group of contributors. That alone is a remarkable accomplishment, but it was not foreordained that their achievement would be shared by a wider public or contribute to our understanding of Greek civilization in Italy. In fact, I had serious doubts that it would ever see the light of day, simply because of the mountain of material that remained to be studied-30,000 pottery fragments alone, not to mention the terracottas, loom weights, coins, metal finds, and plant and animal remains - that resulted from all those years of excavation.

What was needed was a sizable team of specialists with a solid foundation in the study of excavated material of all sorts. The site was protected and carefully maintained from the time of its discovery, and excavated materials safely guarded in the Museo Nazionale of Metaponto. In Italy, training in the study of pottery and excavated materials is rigorous and widespread - a proud tradition-but employment in archaeology for years has been precarious at best. In a rare alignment of the stars, a once-in-a-lifetime opportunity for all involved, Dr. David Packard (of the Packard Humanities Institute, or PHI) had since 1999 generously funded the Institute of Classical Archaeology's (ICA) project at Chersonesos in Crimeabut he had also provided funding for a study project aimed at publishing the results of a quarter-century of fieldwork in the chora of Metaponto. Dr. Packard recognized the unique opportunity of adding signifi- cantly to our knowledge of Greek southern Italy and at the same time of creating a team of highly trained specialists to achieve that goal. The Chora of Metaponto series, on excavated and surveyed sites in the chora of Metaponto, is one result of that decision.

In acknowledging the many contributors to this work, I shall begin with the most recent, the publication, and work backward chronologically to the early years and to the generosity of our hosts and those who supported the project financially from early on down to the present.

\section{The Study Team}

Study of the results of the work at Pantanello began almost immediately, and a preliminary report was made as early as 1977 , after three years of excavation. Some specialist studies were essentially completed already in the 1980s: for example the work of the Costantinis, Donald Sullivan's study of the pollen, and Sandor Bökönyi's of the faunal evidence (revised and updated here by László Bartosiewicz). ${ }^{1}$ Without a comprehensive study of the pottery, however, the chronological development of the site could not be confidently traced. Study for the present volumes began in earnest with the first PHI grant, in 2000. In mid-winter of that year, Rebecca Ammerman and Mary Malone launched an investigation of the terracotta figurines and the many hundreds of fragments of terracotta votive plaques.

The challenge of approximately 300 crates of pottery, washed, sorted, and recorded as to findspot faced Keith Swift. Keith benefited from his earlier experience with the comparably vast body of pottery from the archaeological field survey of the chora of Metaponto. $^{2}$ That study, published in 2011, established the basic typologies of the shapes and fabrics in use in the chora for its three and a half centuries (late 7th to early 3rd centuries BC), the same span applicable to the Pantanello Sanctuary. Keith went through all the pottery from the site to establish the contexts and date

\footnotetext{
$\overline{1}$ E.g. Carter 1983a, 1994.

2 Survey, vol. 1.
} 
them. This was long and lonely work: Metaponto in the winter months can be depressing, but Keith persevered and triumphed. He created catalogs of many of the major classes and illustrated them with his own drawings, making use, principally, of his studies of the Archaic fine wares and the black-gloss pottery. All of the contexts were well dated by 2011, and at last it was possible to date every area of the site and trace its development across the four principal phases. Coins, definitively studied by Anna Rita Parente, document the major periods and show that the site of the Sanctuary continued to attract visitors long into the Roman and Medieval periods. Keith was joined in the pottery study by Eliza Lanza Catti, an expert on Gnathia ware, and Emanuela Conoci on the lamps. Francesca Silvestrelli, who has written a definitive study of the kerameikos of Metaponto and its production (sadly still unpublished), undertook the figured wares - the Attic black- and red-figured pottery, and the Lucanian and Apulian red-figured wares-which were, for a sanctuary, surprisingly abundant. She was able to identify the shapes and in some cases the workshops of even very small fragments, providing exceptionally accurate context dates and contributing also to an understanding of the nature of the worship.

Rebecca Ammerman brought her years of experience with the terracottas of Poseidonia/Paestum, the sister colony of Metaponto, to bear on the material from Pantanello. Her work is fundamental for understanding the cult. She was assisted in the reconstruction of the fragmentary plaques by the multi-talented Massimo Barretta, who also contributed drawings of pottery and other objects, as well as his own study on a rare ceramic item, the lásana. The study of the numerous loom weights from the Sanctuary by Lin Foxhall added a major new dimension to our understanding of the cult and the role of women in it. Metal objects were, in contrast, not numerous, but Marta Mazzoli's discoveries have yielded important insights.

Without the wide-ranging and detailed study of the architectural elements recovered from the Pantanello Sanctuary excavation, we would have been left wondering about them and about the structures from which they originated-above all about the previously unrecognized temple that rose in the Upper Sanctuary ca. $500 \mathrm{BC}$, and other buildings that left few but unmistakable evidence of their existence. This was the work of Carlo Rescigno and his team of Francesco Perugino and Nicoletta Petrillo. Their study of the tile roofing systems, an integral part of every ancient structure from the 6th century $\mathrm{BC}$, is a valuable and very original contribution.

Massimo Limoncelli's computer-based reconstruction of the structures on the site reflect his meticulous attention to archaeological and architectural detailand his patience as the research advanced, making many changes imperative. Thanks to Ann Patterson's drawings, the reader has an overall vision of how the Sanctuary, both Upper and Lower areas, would have appeared in the major periods. Ann was the excavation architect in 1982 and continued her work on the site. She knows its structures and its topography intimately, and was the ideal person to present a comprehensive vision of it, in a series of drawings based on her own first-hand knowledge.

The work of restorers Francesca Quarato, Vita Quattromini, Antonietta Borné, and Maria Giacovelli has supported the research, as has that of photographers Barbara Bini, Cesare Raho, Giambattista Sassi, and Maria Luisa Giuliani. And none have done more to document ICA's work than Chris Williams, who since 1979 has contributed excellent photography and much else-including the handsome annual reports of ICA - to the success of our projects.

The study of the ancient environment of Pantanello began in the late 1970s and has gone forward more or less continuously since then. The first results of water sieving in 1978, Lorenzo Costantini's realization of the importance of the discovery of ancient plant remains, and his enthusiasm for the research opened new vistas for ICA - its first truly interdisciplinary research, which became a hallmark of our future work in the field. The study was renewed with important contributions in the years immediately preceding this publication. Utilizing important new techniques of analysis and a greatly expanded body of comparative material, Anna Maria Mercuri and Assunta Florenzano of the University of Modena have reconstructed the plant landscape surrounding Pantanello. Jim Abbott, who carried out a major geomorphological analysis of the chora of Metaponto (which appears in Survey vol. 1), returned to offer a site-specific analysis of the geological situation of the Sanctuary, while the team led by Andrea Zerboni analyzed the processes by which the Lower Sanctuary came to preserve organic material, as few other sites in the Mediterranean. A whole class of organic material, the marine shells, found in very large numbers in the Pantanello Sanctuary, had been 
virtually ignored until Cesare D'Annibale recently undertook to study it. Cesare pioneered the archaeological field survey of the chora in 1981 and led it for many years. This study is one of the first from southern Italy and it relates very directly to the worship in the Sanctuary.

\section{The Publication Team}

The records of excavation and all other studies, the permanent archives of ICA, reside in its offices in Austin, in hard copies and in digital form. The work of turning a manuscript into a book, translating and editing, the preparation of the illustrations, graphics, and photographs, and the layout of its pages, take place there also. The process of preserving the archives and utilizing them to produce books has developed more in the last decade and a half than any other work that ICA employees do. The first major change was made when Alberto Prieto and Peter Dana developed the Metaponto GIS for the study of the results of the survey. Jessica Trelogan took it further, to the point that it is fundamental for all of our studies and maps. Soon after, Jessica introduced a site GIS for the Pantanello Sanctuary and many other sites in the chora excavated by ICA, expressing geospatially the massive amount of data that has been collected and analyzed by ICA over the years. The introduction of this technology and its masterful implementation by Jessica has resulted not only in a simplified process for producing maps and plans for study and presentation, but also in its own series of scientific discoveries about the landscape of the chora.

A parallel development of Jessica's is the Pantanello ARK, an online database which presents all of the excavation data, with coordinates, plans, objects, context information, photographs, and drawings together. All of this is described with admirable clarity in Ch. 56 by Jessica and Lauren Jackson, who assisted in the development of this highly integrated system. The ARK database has enabled team members, located in the US, Europe, and around the world, to have the information they need at their fingertips, and to be able to communicate and exchange their own results rapidly with other team members, which has been crucial for such an international, interdisciplinary project. The database also serves as a companion to this volume, an invitation to critical readers to examine for themselves the data collected and to draw their own conclusions. Jessica's is a remarkable achievement in the push for full scientific data publication in archaeology.

The work of more than a dozen and a half contributors to these volumes has been coordinated by Lauren Jackson. She reads and edits every manuscript, queries the authors, checks references, and manages the work of the publication team, maintaining our good relations with and adhering as much as possible to the schedule of the University of Texas Press. This is stressful work and Lauren has carried it out with calm, cheerful, and firm determination. The atmosphere she has created in the Austin office is one of friendly and productive collaboration. In addition to Lauren, the publication team consists of graphic designers Juan Carlo Fernández and Karl Strasen, whose job it is to prepare painstakingly each photograph, drawing, and illustration for publication, and editorial assistant Emily Harris, who also works directly with the texts. Their monumental effort to produce this substantial work is to be commended. When all is said and done, that these volumes reached the printer as carefully edited and as promptly as they did is largely due to Lauren.

All the while the manuscript was in the works, Jessica and Lauren have been involved in the preservation of the ICA archives, a massive project that has proved essential for these volumes, and critical for the future of as-yet-unpublished excavation projects and other studies in the chora of Metaponto, Croton, and Chersonesos. The basic documentation (photography, archives, field notes, cartography) is in the process, now, of being digitized.

An able administrative team in Austin, consisting at various times, of Leoda Anderson, Cynthia Valerio, Carol Cook, Pat Irwin, Esmeralda Moscatelli, and Matthew Rabatin, kept the whole operation in Italy and Austin running smoothly, dealing with everincreasing bureaucratic burdens. Esmeralda worked closely with Tiziana Ria and coordinated work with the Soprintendenza and administration of the Museo Nazionale to assure that the researchers based at the Centro (di Agroarcheologia) at Pantanello were regularly paid, fed, and provided with transportation between our office there, the sites, the storerooms in the Museo Nazionale, and our workplace, the "Banca," in Metaponto Borgo. Tiziana, librarian and administrator of the Centro after Rosetta Torraco, also sees to the maintenance of the site at Pantanello, by the Azienda in the person of Domenico D'Anzi and by Giuseppe Di Taranto. 


\section{The Excavation Teams}

The site was chosen in the fall of 1973 . The first excavation team, whose work is chronicled in Ch. 3, consisted of volunteers - three to four of them (the number fluctuated) from The University of Texas, the British School in Rome, and the American community in Rome - and an Italian workforce of three: two from Bernalda and one from Montescaglioso. Lunches were organized on the site by a young Roman, Daniela Bini, who in 1976 became my wife and lifelong partner. The entire campaign lasted just three weeks, and was funded by a grant of $\$ 3,000$ from the Dean of the College of Humanities. The beginning was auspicious. The site promised well, because we understood and appreciated the competence and goodwill of the Italian workforce.

\section{The Students and Volunteers}

The pattern of the work was established in the first years. The volunteer students of archaeology were responsible for keeping notes of the excavations and recording the pottery and special finds. Looking back now and having had to rely on their documentation, I can say with very few exceptions they worked conscientiously and well. Reflecting on the campaigns at the Sanctuary site that ran from 1974 to 1982 without interruption and were reprised in 1990-91, 2008, and 2013, I stand in admiration of these young people, many of them Texans. I have made an attempt to recall the names of the participants and have probably missed some. I hope that they will not take offense. Forty-two years have passed since that first day. Some of them stand out in my memory because of their personalities, enthusiasm, skills, and dedication. How could I forget Sue Andrews or Nancy Jircik from the early years, or Jack Englert and his meticulous and thoughtful notes. He refused to wear a hat even on the hottest days (it did not do him permanent harm-he is a successful lawyer in Denver). Or Tom Hale, scrupulous in his work and irrepressibly good-humored in the field, and Ginger Hale, indefatigable organizer of the pot shed. Kate Monahan wanted to have an archaeological experience before business school. Vera Massaro signed up to help with the Ancient Crossroads exhibition and stayed. That this early group of young people, who have gone on to greater things, still remember their experiences at Pantanello with pleasure, and return and reunite in Austin and elsewhere is one of the great satisfactions of my career.
All serious about the work but at the end of the workday ready to play. As far as groups go, this was a remarkable one, not only for their individual skills and personalities, but for the way they worked together. There was, as I recall, much fun and laughter, unspoiled by prima donna behavior. As the discoveries grew and the site became more complex and scientifically important, the team expanded first to include more advanced students. We were lucky to have Michael Guarino and Ann Patterson from the UT School of Architecture, Boyce Cabaniss, a budding palaeobotanist from geology, Sandra Langston from the Art Department, and Ingrid Edlund, a soon-to-be UT Classics faculty member who helped supervise during the very busy 1977 and 1978 campaigns. They are happy to admit that the Pantanello experience helped to determine their future careers and shape their lives.

\section{The Italian Workforce}

I had had some earlier experience with local laborers at sites in Turkey and elsewhere in Italy, but nothing prepared me for the workmen of Bernalda and Montescaglioso. The first things that impressed me were their pride and their capacity for work. It seemed to be a point of pride to work the full eight hours without slowing down except for water and an occasional cigarette. Alfredo Gallitelli set an example. I soon became aware that these men, who had very few years of formal schooling, knew their jobs very well, knew the soil, and could read the changes. Some were naturally more skilled than others. I came to rely very early on a man of exceptional intelligence, Giuseppe Di Taranto of Montescaglioso, who is credited here, justly, as the discoverer of the Sanctuary. He showed up the first day, June 23, 1974, but did not appear on the morning of the $24 \mathrm{th}$. I was naturally upset, until I learned that he had spent the morning in hospital awaiting the birth of his child, Vincenzo. From that day onward, Di Taranto was involved in every excavation that ICA carried out, not only at Pantanello, but elsewhere in the chora. He excavated on the site as late as 2013, and has continued to maintain it down to the present. The practical lessons and insights of $\mathrm{Di}$ Taranto and others enriched my largely book-learned archaeology and made me a far better archaeologist. Some of the group came with special skills. Leonardo Pacciani, for example, was a master with the small bulldozer (or ruspa) - he could wield it like a scalpel. With Di Taranto monitoring, we were able to remove 
much archaeologically unimportant overburden, saving weeks or even months of precious time. When Di Taranto detected the slightest change in soil color and composition, he would enlarge the area to be sure the feature was fully exposed before excavation. Always expand - that was the lesson we all learned, and that is how the Sanctuary was finally totally exposed.

Honesty is a basic requirement of science and the team was never less than straightforward with me and the student note takers. We respected their judgments and worked along beside them, and very quickly there was an atmosphere of collaboration and mutual respect that developed into friendship in many cases. I recall them with nostalgia and gratitude. I had never met a group like this, and I fear that archaeologists will not find their equals in the future. Mechanization and education (for better or worse) has devalued the work of hands and backs, and removed a source of pride from the working man and woman. The Italian workforce included some extraordinary women, like Annaluce Marino, a talented draftsperson of infectious optimism, and Francesca Quarato, our highly skilled, joyful, and indefatigable restorer for many years.

The schedule was rigorously observed. Every day at noon, the entire team would adjourn to a bank shaded by eucalyptus for lunch. The workmen unpacked home-cooked meals their wives would send in insulated containers, along with homemade wine which they shared with us-Favori! - and we would gratefully accept. Generosity was and I hope will always be a prime virtue of the Italian contadino of the south. Its corollary, hospitality, was also often observed. We were invited into homes in Bernalda, Montescaglioso, and Pantanello (Casa Torraco). Limited in our ability to reciprocate in kind, we offered a festa at the end of the campaign, beneath those same eucalyptus trees under which we lunched. There we feasted on roast lamb, young goat (capretto), the wonderful bread of Montescaglioso, and that wine of which we could never find an equal in a bottle. The festa began at $1 \mathrm{pm}$ and went on with music and dancing until dark. Thirty years later, the feste are legendary. Life-long friendships have developed between the students and their coworkers.

\section{Our Italian Hosts \\ The Soprintendenza}

It was great good fortune to begin this project at the invitation of Dinu Adamesteanu. The Soprintendenza was always encouraging and collaborative-that was the atmosphere from the beginning and it continued, despite inevitable changes in personnel, down to the present. Whether we were on the site at Pantanello or in the offices of the Scavi (excavation) of the ancient city at Metaponto, or in the headquarters of the Soprintendenza in Potenza, the warmth and cordiality was felt-from the museum guards, restorers, assistants, and colleagues, Italian and foreign, to the Soprintendente himself, Dinu. We were friends working toward a shared goal. I remember with particular gratitude the constant aid and advice I received from Dieter Mertens and Antonio De Siena, who shared unreservedly their first-hand knowledge of the ancient city, and encouraged my efforts in the chora-two aspects, as it were, of the same reality. If there were exceptions to this generosity of spirit, they were few and I have forgotten about them. This may sound overly idealizing, and perhaps just a little too good to be true-after all, the memories have been filtered over many years-but it was essentially so! Otherwise we would never have reached this goal.

The site, Pantanello ("little swamp"), was chosen by Dinu. Nothing was visible on the surface in the fall of 1973 when I first set eyes on it but a few ancient roof tiles to indicate what might lie beneath the surface. Others might have been discouraged, but we were not looking for architecture or a sanctuarythough in fact they were there. We were inspired by the idea of discovering the ancient countryside, a new frontier that was given substance by the early discoveries of the pioneers - of which Dinu was one of the foremost. The early survey of the chora of Metaponto in the mid-1960s and the excavation of farmhouses opened up a new world that we were eager to explore. It was no accident that in the 1970s Pantanello became the starting point of a renewed widespread and multifaceted exploration of the chora. It followed on that of the Soprintendenza in the mid-1960s and continued that inspired work and over the course of the past 40 years expanded on it. Dinu had the vision of the totality of the human occupation of the Greek and indigenous territory and was open to a wide range of evidence for it. He made possible and exhibited the results of the first four years of research at Pantanello and Incoronata in the United States, and took part in a semester-long symposium, "Ancient Crossroads," sponsored by the National Endowment for the $\mathrm{Hu}-$ manities (NEH). On that occasion he championed for the establishment of an institute, ICA, to continue 
research on Greek settlement at Metaponto. We were extremely fortunate that Dinu's successors, Elena Lattanzi and Antonio De Siena, shared his enthusiasm and desire for international collaboration. Pantanello proved to be a brilliant choice of site for excavation, not only from an archaeological point of view, but from an administrative one.

Besides encouragement and moral support, the Soprintendenza provided the excavation project vital infrastructure: space to work on finds, restore, and document them. First, we were offered room in the venerable Casa Teresa (near the Tavole Palatine, the Temple of Hera on the Bradano), and then in the $\mathrm{Mu}-$ seo Nazionale of Metaponto (1990) and an adjunct structure with ample space, the laboratory known as the "Banca" - all within easy reach of the site, our living facilities, and the Museo.

\section{The Region}

After the expropriation of the land where the Lacava family raised oxen in the agrarian reform of the 1950s, the land was designated for agricultural experimentation first by the Ente Irrigazione di Bari (1962-81), in the person of Ing. Salvatore Dedono, who regularly visited the excavation. In 1981, the region of Basilicata took over: besides a center for the diffusion of new methods in agriculture (CIFDA), and the experimental farm "Azienda Sperimentale Pantanello," there was also in the 1980s a germ plasm bank of the Centro Nazionale di Ricerca (CNR), which preserved the seeds of vital crops from around the world for eventual hybridization. A center for plant research, the Metaponto Agrobios, was established in 1985, right beside the building lent from the first year as workspace for the UT expedition. A quarter-century later, it became our library, study, and conference room. It seemed providential that on the very same site there should be an archaeological excavation in part at least devoted to the recovery of evidence of the plants raised by the ancient inhabitants and of their natural environmentthe fullest evidence of actual plant life and its history from any Greek Classical site in the Mediterranean.

We have been the fortunate guests of the Region of Basilicata for nearly four decades, benefitting much of this time from the benevolent advice and guidance of Salvatore Martelli, the Director of the Azienda Sperimentale (1981 to the mid-1990s), and enjoying from the beginning the friendship and warm hospital- ity of Leonardo Torraco, the Capo Azienda, and his wife Antonietta and their children, Rocco and Rosetta. Their summer home was a comfortable two-story farmhouse, the terrace of which overlooks the archaeological site of the Sanctuary. Leonardo retired in 1999, and in that year, the Assessore ("Councilor") of Agriculture for the region and ICA signed a convention creating the Centro di Agroarcheologia. The mission of the Centro is to continue to explore the history of agriculture in Basilicata and to disseminate that knowledge to scientific and public audiences. The ICA team would continue to make use of the building that had served as a work space and library, and in addition, the Torraco home, which became a living quarters for the excavation and study teams after its restructuring in 1999.

\section{Our Contributors}

The support of private individuals and foundations was crucial to the success of the Pantanello Sanctuary project (as for all ICA projects) from the very beginning down to the present. For the first few years, the University of Texas provided a limited amount of seed money through the College of the Humanities (later reorganized as the College of Liberal Arts, or COLA). In recent years under Dean Randy Diehl, COLA has again provided significant support. The contributions of private individuals and foundations were instrumental in getting the Metaponto project off the ground after a first trial session in 1974, and they were essential after that. This was a remarkably loyal group. Among them I could count good friends, whose checks were both very generous and very consistent. Year after year, through the first quartercentury and beyond, I would write to them all in the spring before the campaign. At the end before leaving Italy, I would compose a hand-written letter accompanied by a dozen or more snapshots of the action. Most contributed all their lives, and I wrote to them all as the dear friends I considered them to be. Some have assumed that because I was based in Texas that of course support was not a problem. It was in fact work, but work I enjoyed, because these supporters became friends able to consider themselves partners in an exciting enterprise.

Among the first and most loyal were Ben Vaughan through the James R. Dougherty Foundation and Ralph and Maconda O'Connor via the Brown Foun- 
dation. After 1977, these private contributions were matched one-to-one in successive three-year grants by the NEH, which helped this project develop in interesting new ways, thanks to the peer review process. The archaeologists who reviewed were often from other areas of the field, and with their encouragement, our project became interdisciplinary, which in a few years became its hallmark. The most original aspects of ICA's projects-interest in palaeobotany, geology, archaeozoology, and human biology-all developed between 1977 and 1985, and coincide with important discoveries of the preserved organic materials including human remains, at Pantanello above all but also elsewhere in the chora. The Metaponto project is an excellent example of private-public partnership applied to research in the humanities. It was not to last.

In 1994, I was in the process of applying for another three-year grant to $\mathrm{NEH}$ in order to begin the study of our results from the Pantanello Sanctuary for publication. Grants in aid of publication were a very enlightened and welcome move by the $\mathrm{NEH}$, since funding for publication is much harder to obtain than to begin or continue an exciting excavation project, despite the fact that failure to publish the results deprives the public of any benefit from the excavation project. In that year, Congress voted to cut back funding to $\mathrm{NEH}$ drastically, eliminating this new initiative. Three years passed, and with support largely from private donors and from IREX (International Research and Exchange Board), ICA focused its efforts on Chersone- sos in Crimea. Then in 1997, I received a telephone call from Dr. Packard, who had read a story about our work at Chersonesos and offered to help us "realize our dreams"-both for Chersonesos and for Metaponto. You have read above how Dr. Packard made it possible to assemble a group of highly-trained scholars and students from the US and Europe to undertake the study of the Metaponto projects for publication, with a special emphasis on the Greek civilizationthe period and culture known as Magna Grecia. The publication series has now reached 13 volumes (seven titles) and our promise to put Metaponto on the map of archaeologists and historians of ancient Greece has been met (albeit far from fully realized). In addition to making this new humanities knowledge available, the PHI grants have made it possible for students and the general public to acquire the volumes at very reasonable prices. Funding is essential for real progress in any scientific endeavor. In archaeology, time is equally so. David Packard realized this at the beginning, when he asked me how long it will take. I replied, "Twenty years." So it has-and it took all of that to produce these results. NEH had a good idea, but it depended on politicians. David Packard's long-term commitment to research in the humanities is truly visionary. All students of Magna Grecia owe PHI and David Packard an enormous vote of thanks, and I in particular, for helping me to realize the dream of a lifetime.

March 2017 
La scoperta del Santuario avvenne 43 anni fa, nel giugno del 1974 durante il primo scavo a Pantanello nella chora di Metaponto. Sarebbero intraprese nei prossimi anni intensive compagne di scavo - dodici in totale - e molti anni di studio che fino al 2016, hanno raggiunto conclusioni molto importanti. Speriamo che i tre volumi presenti, presentando prove e reperti, stimolino ulteriori ricerche. Gli scavi, l'analisi, e la pubblicazione dei volumi sono il frutto di molti anni d'impegno e di studi svolti da un grande numero di persone di talento che lavorano insieme da più di quarant'anni, e sostenuti finanziariamente e moralmente da contributori leali motivati dal desiderio di conoscere meglio la civiltà greca in Italia. Dubitavo, però, che questo progetto potesse realizzarsi in una pubblicazione dome questa, considerando l'enorme quantità di materiale - 30,000 frammenti di ceramica, per non parlare delle terracotte, $i$ pesi da telaio, le monete, i reperti di diversi tipi di metalli, e i resti di piante e animali - che sono il frutto di tutti quegli anni di lavoro e d'impegno.

Occorreva una squadra di specialisti che avessero una solida conoscenza dei materiali di scavo di tutte le specie. Sin dalla sua scoperta, il sito è stato tutelato e mantenuto con cura, e i reperti depositati e conservati nel Museo Nazionale di Metaponto. È rigorosa e diffusa in Italia la formazione nello studio di questi materiali: una lunga tradizione svoltasi con orgoglio. Purtroppo, le possibilità di lavoro in campo archeologico sono state per anni molto scarse. Per un colpo di fortuna, si presentò un'occasione che capita una volta sola nella vita. Dr. David Packard (del Packard Humanities Institute, ovvero PHI), che sin dal 1999 aveva sostenuto con generosità lo scavo dell'Istituto di Archeologia Classica a Chersonesos in Crimea. Sono pervenuti anche fondi destinati alla pubblicazione dei resultati di venticinque anni di lavoro e studi sulla chora di Metaponto. Il Dr. Packard vide in quel momento l'occasione di approfondire la conoscenza dell'Italia meridionale greca e, nello stesso tempo, quella di assemblare una équipe di ricercatori di grande talento i quali potessero raggiungere tale meta. Dalla sua decisione risultò The Chora of Metaponto, una collana di pubblicazioni sui siti scavati e scoperti nella chora di Metaponto.

Per ringraziare $\mathrm{i}$ contributori i cui studi appaiono in questi volumi, comincerò con la pubblicazione e continuerò a ritroso per arrivare ai primi anni dello scavo e a coloro che ci hanno ospitato, i quali, con la loro generosità hanno sostenuto finanziariamente il progetto sin dalle prime scoperte fino ad oggi.

\section{Gli studiosi}

Lo studio dei risultati del lavoro a Pantanello fu avviato quasi subito, e dopo solo tre anni di scavo, ne fu fatto un resoconto preliminare nel 1977. Alcuni studi specialistici sarebbero stati portati quasi a conclusione già nel seguente decennio: ad esempio, il lavoro dei Costantini, lo studio del polline di Donald Sullivan, e lo studio dei reperti di fauna di Sandor Bökönyi (riveduto e aggiornato da László Bartosiewicz). ${ }^{1}$ Senza uno studio esauriente delle ceramiche, tuttavia, non si sarebbe potuto rintracciare lo sviluppo cronologico del sito. I lavori di studio che appaiono qui nei presenti volumi presero forma nel 2000, a seguito della prima sovvenzione del PHI. Nell'inverno dello stesso anno, Rebecca Ammerman e Mary Malone intrapresero una ricerca sulle figurine di terracotta e sulle centinaia di frammenti di targhe votive di terracotta.

A Keith Swift venne assegnato il compito di esaminare circa 300 casse di ceramiche lavate, ordinate e classificate per la zona di ritrovamento. Keith poté sfruttare l'esperienza fatta sul corpo di ceramiche, relativamente vasto, rinvenute durante i sopralluoghi nella chora di Metaponto. ${ }^{2}$ Quello studio, pubblicato nel 2011, stabilì le principali tipologie delle forme e tessuti in uso nella chora durante $\mathrm{i}$ suoi tre secoli e mezzo (dal tardo settimo secolo al primo terzo secolo a.C.), un periodo cronologico che si può applicare al coevo santuario di Pantanello. Keith Swift esaminò tutte le ceramiche del sito con lo scopo di stabilire i loro contesti e la datazione. È stato un lavoro lungo e faticoso: nei mesi invernali Metaponto è abbastanza triste, ma Keith ha perseverato. Ha così creato i cataloghi delle maggiori classi e ha illustrato i suoi disegni adoperando principalmente gli studi fatti da lui stesso delle ceramiche arcaiche e quelle a vernice nera. Entro il 2011, tutti i contesti erano stati datati, e finalmente fu possibile datare ogni zona del sito e rintracciarne lo sviluppo attraverso le sue quattro fasi principali. Le monete, studiate in modo definitivo da Anna Rita Parente, documentano i maggiori periodi e dimostrano che il sito del Santuario ha continuato ad esercitare il suo fascino fino ai periodi romani e medievali. Elisa Lanza Catti, un'esperta nelle ceramiche di Gnathia, e Emanuela Conoci, che ha lavorato sulle lucerne, hanno contribuito insieme a Keith allo studio delle ceramiche. Francesca Silvestrelli, che ha scritto uno studio esauriente della kerameikos di Metaponto (purtroppo

\footnotetext{
${ }^{1}$ E.g. Carter 2006, ch. 1; Archaeozoology.

${ }^{2}$ Survey, vol. 1.
} 
ancora non pubblicato) e la sua produzione, si assunse lo studio dei vasi a figure - le ceramiche attiche sia quelle a figure nere e rosse, sia quelle a figure rosse provenienti dalla Puglia e dalla Basilicata - una quantità notevole per un santuario. Francesca è riuscita a identificare le forme e in alcuni casi il luogo di produzione perfino dei frammenti più piccoli, fornendo delle accuratissime datazioni dei contesti e contribuendo ad una conoscenza più ampia della natura del culto.

Nei suoi studi sul materiale di Metaponto, Rebecca Ammerman ha portato con sé anni di esperienza con le terrecotte di Poseidonia/Paestum, la colonia sorella di Pantanello. I suoi studi sono fondamentali per capire il culto. Nella ricostruzione dei pinakes votivi, è stata assistita da Massimo Barretta, il quale ha anche fornito non solo disegni e lucidi di ceramiche e altri reperti, ma anche uno studio di una rara forma, i lásana. Lo studio dei numerosi pesi da telaio rinvenuti nel Santuario scritto da Lin Foxhall ha aggiunto un'ulteriore dimensione alla nostra conoscenza del culto e del ruolo delle donne in esso. Al contrario, gli oggetti di metallo non erano, invece, altrettanto numerosi, ma le scoperte di Marta Mazzoli hanno fornito informazioni importanti.

Senza lo studio comprensivo degli elementi architettonici ritrovati nello scavo del Santuario a Pantanello, continueremmo ancora a farci domande su di questi, sulle strutture e sulla loro provenienza, e soprattutto sul tempio costruito nel Santuario in alto nel 500 a.C. circa, e infine sulle altre costruzioni che lasciarono poche ma inconfondibili tracce della loro esistenza. Queste osservazioni sono il frutto dello studio di Carlo Rescigno, Francesco Perugino, e Nicoletta Petrillo. È originale e di grande valore archeologico il loro studio dei sistemi di copertura in tegole, una parte integrale di ogni struttura antica del 6o secolo A.C.

La ricostruzione digitale delle strutture del sito completata da Massimo Limoncelli mette in evidenza sia la sua meticolosa attenzione ai dettagli archeologici sia la sua pazienza quando nuove scoperte e conclusioni esigevano cambiamenti al progetto. Grazie a Ann Patterson e ai suoi disegni, il lettore può vedere come appariva all'epoca il Santuario, in entrambe le sue zone alta e bassa. Ann è stata, nel 1982, l'architetta dello scavo e ha continuato anche in seguito i suoi lavori nel sito; ne conosce intimamente le strutture e la topografia, ed è stata la persona ideale per fornirne una ricostruzione in una serie di disegni in questo volume.

L'attività di ricerca è stata appoggiata dal lavoro delle restauratrici Francesca Quarato, Vita Quattro- mini, Antonietta Borné, e Maria Giacovelli e dei fotografi Barbara Bini, Cesare Raho, Giambattista Sassi, e Maria Luisa Giuliani. Più di ogni altro, Chris Williams ha documentato sin dal 1979 il lavoro dell'ICA e contribuito al successo dei nostri progetti con le sue fotografie eccellenti e con il disegno dei resoconti annuali dell'ICA.

Lo studio della zona antica di Pantanello ebbe inizio nella seconda metà degli anni 1970 e il lavoro è continuato finora. I primi semi antichi dallo scavo del 1978, la comprensione da parte di Lorenzo Costantini dell'importanza della scoperta, e il suo entusiasmo hanno aperto nuove strade per l'ICA - l'interdisciplinarietà dello studio sarebbe diventato col tempo l'elemento caratteristico del nostro lavoro. Negli anni precedenti la presente pubblicazione, lo studio è stato rinnovato tramite altri contributi rilevanti. Anna Maria Mercuri e Assunta Florenzano dell'Università di Modena hanno riscostruito, utilizzando nuove e importanti tecniche di analisi e un grande corpus di materiali comparativi, il panorama della flora nei dintorni di Pantanello. Jim Abbott, che aveva svolto una considerevole analisi geomorfologica sulla chora di Metaponto (l'articolo è apparso in Survey vol. 1), è ritornato per offrire un'analisi contestualizzata della posizione geografica del Santuario. Il gruppo guidato da Andrea Zerboni ha esaminato i metodi attraverso i quali il Santuario in basso, come pochissimi siti nel Mediterraneo, diventò un luogo adatto alla conservazione di materiale organico. Finché Cesare D'Annibale non ne intraprese uno studio, un'intera classe di materiale organico, le conchiglie marine, di cui una grande quantità fu ritrovata nel Santuario di Pantanello, era rimasta ignorata. Cesare diede inizio prima alle ricognizioni archeologiche della chora svoltasi dal 1981 e le ha guidate per molti anni. Il suo studio dei molluschi è uno dei primi studi dell'Italia meridionale e si collega direttamente al culto del Santuario.

\section{La redazione}

L'archivio dell'ICA - la documentazione degli scavi archeologici e ogni altro studio legato ad essi - si trova, in forma sia digitale che cartacea, presso il suo ufficio ad Austin, Texas laddove si sono svolti i diversi lavori editoriali del presente volume: le revisioni e la traduzione, la preparazione delle illustrazioni, fotografie e della grafica, nonché l'impaginazione. Negli ultimi 15 anni, si è sviluppato il processo di conservazione degli archivi e il loro uso per la pubblicazione dei testi. Il 
primo cambiamento importante avvenne quando Alberto Prieto e Peter Dana crearono il Sistema di Informazioni Geografiche (il GIS) di Metaponto per lo studio dei risultati delle ricognizioni. Jessica Trelogan ha continuato il lavoro, sviluppandolo fino al punto che il GIS è ormai un elemento fondamentale per la creazione delle nostre cartine e l'organizzazione dei nostri studi. Poco dopo Jessica ha creato il GIS per il Santuario di Pantanello e per molti altri siti scavati dall'ICA nella chora; i GIS rendono visibile in maniera geospaziale una grandissima quantità di dati che è stata raccolta e analizzata dall'ICA nei suoi anni di attività. L'arrivo di questa tecnologia e la maniera magistrale con cui Jessica ha realizzato i siti hanno portato non solo ad un processo più semplice per produrre mappe e cartine da studiare e mostrare, ma anche ad una serie di scoperte scientifiche nel paesaggio della chora.

Un altro contributo di Jessica, legato direttamente anch'esso al GIS, è l'ARK di Pantanello, un database in rete che documenta e presenta i dati degli scavi insieme alle coordinate, $i$ piani, $i$ progetti, l'informazione sul contesto, le fotografie e i disegni. Tutto ciò viene descritto con chiarezza da Jessica e Lauren Jackson, che ha partecipato con Jessica alla realizzazione del sistema informatico. Il database ARK ha permesso ai ricercatori dell'ICA, sparsi come sono per gli Stati Uniti, l'Europa, e il mondo intero, di avere a portata di mano i dati necessari e di poter comunicare e scambiare velocemente i propri risultati con altri ricercatori, fatto che si è rivelato decisivo per un tale progetto al contempo internazionale e interdisciplinare. Il database fa da compagno a questo volume e insieme sono un invito ai lettori ad analizzare i dati per poi arrivare alle proprie conclusioni. Questo contributo è notevole in quanto è uno stimolo alla pubblicazione dei dati e dei risultati scientifici nell'ambito dell'archeologia.

Il lavoro di più di 18 contributori ai presenti volumi è stato organizzato e coordinato da Lauren Jackson. Lauren legge e rivede ogni manoscritto, pone quesiti agli autori degli studi, controlla i riferimenti nei testi, dirige l'équipe di redazione, e mantiene buoni rapporti con la University of Texas Press tenendo sempre presente il calendario di lavoro dell'ICA. Le responsabilità sono tante è anche molto stressanti, ma Lauren le ha sempre eseguite con calma e appassionata determinazione. Nella sede dell'ICA ad Austin, Lauren è riuscita a creare un'atmosfera di collaborazione e cordialità. Oltre a Lauren, fanno parte della redazione i grafici Juan Carlo Fernández e Karl Strasen; essi preparano meticolosamente e con gran cura ogni fotografia, disegno, e illustrazione per le pubblicazioni. Emily Harris, assistente editoriale, aiuta Lauren nella preparazione dei testi. I loro sforzi lodevoli sono valsi a portare a termine questo progetto. Dobbiamo essere infatti grati a Lauren che questi volumi abbiano raggiunto la stampa così prontamente e riveduti con cura.

Mentre si preparavano i manoscritti, Jessica e Lauren collaboravano alla conservazione degli archivi dell'ICA - di per sé è un progetto già molto impegnativo che è stato essenziale per i presenti volumi - e un passo importante per il futuro di eventuali scavi e altri studi sulla chora di Metaponto, Crotone, e Chersonesos. Ci si concentra presentemente sulla digitalizzazione dei documenti di scavo - le fotografie, gli archivi, gli appunti e resoconti, e la cartografia.

Un'abile squadra amministrativa, fatta in vari momenti da Leoda Anderson, Cynthia Valerio, Carol Cook, Pat Irwin, Esmeralda Moscatelli, e Matthew Rabatin, è riuscita a gestire le attività dell'ICA ad Austin e in Italia. Esmeralda ha lavorato in stretto contatto con Tiziana Ria e ha coordinato il lavoro con la Soprintendenza e l'amministrazione del Museo Nazionale con lo scopo di assicurare che i ricercatori venissero pagati, avessero da mangiare e disponessero di trasporto tra il nostro ufficio metapontino, i siti di scavo, i magazzini nel Museo Nazionale, e il nostro luogo di lavoro, la "Banca", a Metaponto Borgo. Tiziana, la bibliotecaria e amministratrice del Centro dopo Rosetta Torraco, si occupa della manutenzione allo scavo con l'aiuto del personale, dell'Azienda, in primis di Domenico D'Anzi, e di Giuseppe di Taranto, del sito a Pantanello.

\section{Le squadre di scavo}

Il sito fu scelto nell'autunno del 1973. La prima squadra di scavo, il cui lavoro appare nel Capitolo 3, era fatta di volontari - circa 3 o 4 persone (il numero delle persone è cambiato spesso) dell'Università del Texas, della British School of Rome, e della comunità americana di Roma - e tre italiani: 2 dei quali di Bernalda e l'altro di Montescaglioso. Al sito, il pranzo era organizzato da una giovane romana, Daniela Bini, che nel 1976 divenne mia moglie e compagna di vita. L'intera campagna durò solo tre settimane e fu finanziata da una borsa di studio di 3.000\$ assegnata dal Dean della College of Humanities. L'inizio ci fu di buon auspicio. Il sito prometteva molto anche perché abbiamo subito capito e apprezzato le capacità e la gratitudine dei lavoratori italiani. 


\section{Gli studenti e $i$ volontari}

Fu stabilita in quei primi anni la struttura lavorativa. Gli studenti di archeologia erano responsabili degli appunti di scavo e della registrazione delle ceramiche e degli altri reperti archeologici. Tornando indietro a quegli anni e avendo dovuto adoperare la loro documentazione, posso dire che, tranne alcuni casi isolati, essi lavorarono bene e con grande cura. Riflettendo sulle campagne che erano continuamente in corso dal 1974 al 1982 e riprese nel 1990-91, 2008, e 2013, desidero comunicare qui la mia stima per questi giovani, molti dei quali texani. Ho cercato di ricordare i nomi di tutti i partecipanti, ma probabilmente ne ho dimenticato uno o due. Spero che non se ne abbiano a male. Sono passati 42 anni ormai da quel primo giorno e ora alcuni spiccano nella mia mente per le loro personalità, entusiasmo, e dedizione. Non potrei mai dimenticare in quei primissimi anni Sue Andrews e Nancy Jircik, né Jack Englert, che si rifiutava di indossare un cappello anche nei giorni più caldi e soleggiati: il rifiuto di mettersi un cappello non ha fatto male né a lui - è ora avvocato di gran successo a Denver - né ai suoi appunti scritti con cura; così come ricordo con simpatia Tom Hale, scrupoloso nel suo lavoro e sempre di buon umore, e "Ginger" Hale, organizzatrice infaticabile del capanno per i ritrovamenti. Kate Monahan venne perché voleva fare un'esperienza archeologica prima di cominciare gli studi in economia e commercio. Vera Massaro si unì alla squadra per aiutare con la mostra "Ancient Crossroads" e rimase a farne parte. Il fatto che questo gruppo di giovani, i quali non si fermarono al traguardo e trovarono altre strade nella vita, si ricordi con piacere delle loro esperienze a Pantanello e si riunisca ancora ad Austin e altrove, è una delle più grandi soddisfazioni della mia carriera.

Seri nel lavoro svolto ma pronti a divertirsi, questo gruppo fu eccezionale, non solo per il talento che ognuno di loro possedeva, ma anche per la maniera in cui riuscivano a lavorare insieme. Sono stati bellissimi momenti: si rideva e scherzava e nessuno si atteggiava a "primadonna". Mentre in quegli anni il numero di scoperte aumentava e il sito assumeva sempre maggior importanza scientifica, la squadra crebbe aggiungendo altri studenti. Siamo stati fortunati ad avere Michael Guarino e Ann Patterson della Scuola di Architettura alla Università del Texas ad Austin, Boyce Cabaniss, allora un paleobotanico in erba della facoltà di geologia, Sandra Langston della facoltà di arte, e Ingrid Edlund, una futura professoressa nella facoltà di lettere classi- che, che mi ha aiutato a dirigere le campagne impegnative del 1977 e 1978. La loro esperienza a Pantanello ha avuto una notevole influenza sulle loro future scelte.

\section{La squadra italiana}

Avevo avuto esperienze con operai locali prima in Turchia e in altre località in Italia, ma niente mi aveva preparato a quelli di Bernalda e Montescaglioso. La fierezza e capacità nel lavoro furono le prime cose che mi colpirono. Lavorare tutte le otto ore senza sosta, tranne qualche pausa per prendere un bicchier d'acqua o fumare una sigaretta, era qualcosa di cui vantarsi. Alfredo Gallitelli ne dava l'esempio. Mi sono presto accorto che questi uomini, che avevano probabilmente avuto pochi anni d'istruzione scolastica, sapevano far bene e con grande talento il loro mestiere, che conoscevano il terreno e la terra, e potevano leggerne i cambiamenti. Alcuni erano più bravi degli altri, naturalmente. Molto presto cominciai a contare su un individuo di eccezionale intelligenza, Giuseppe di Taranto, di Montescaglioso, a cui attribuiamo qui, e giustamente, la scoperta del Santuario. Si presentò al lavoro il primo giorno, il 23 giugno 1973, ma il giorno seguente non c'era. Naturalmente mi arrabbiai, ma solo finché non seppi che Giuseppe aveva trascorso la mattina all'ospedale aspettando la nascita del figlio, Vincenzo. Da quel giorno in poi, egli avrebbe fatto parte di ogni compagna di scavo gestita dall'ICA, non solo a Pantanello, ma in altre parti della chora. Ha scavato nel sito fino al 2013 e ha continuato a mantenerlo fino al presente. Le lezioni pratiche di Di Taranto e degli altri arricchirono la mia conoscenza dell'archeologia che avevo imparato all'università, e questo ha fatto sì che diventassi un migliore archeologo. Per quanto riguarda il gruppo, ognuno aveva un talento particolare. Leonardo Pacciani, ad esempio, sapeva utilizzare magistralmente la ruspa così come un chirurgo adopera il bisturi. Con Di Taranto che controllava, riuscimmo a rimuovere terreno alluvionale, cosa che risparmiò mesi di lavoro inutile. Quando Di Taranto notava anche il minimo cambiamento al colore o alla composizione della terra, allargava la zona d'interesse per assicurarsi che l'oggetto o la struttura venisse completamente esposto prima di essere scavata.

Lonestà è uno dei primi requisiti del lavoro scientifico e la nostra squadra è sempre stata chiara e franca sia con me sia con gli studenti che prendevano appunti. Lavoravamo insieme a loro e rispettavamo le loro opinioni. In quell'atmosfera di collaborazione 
si stringevano presto molte amicizie; le ricordo con nostalgia e gratitudine. Non avevo mai conosciuto un gruppo di individui come loro, e gli archeologhi futuri faranno fatica a mettere insieme una squadra simile. La meccanizzazione e la scuola (nel bene e nel male) hanno sottovalutato il lavoro manuale e tolto un senso di orgoglio al lavoratore. Della squadra di operai facevano parte alcune donne eccezionali, come Annaluce Marino, una disegnatrice il cui senso di ottimismo era contagioso, e Francesca Quarato, la nostra gioiosa restauratrice per talento di molti anni.

Lorario di lavoro era rigorosamente rispettato. Ogni giorno a mezzogiorno l'intera squadra pranzava all'ombra di un eucalipto. Gli operai mangiavano il cibo portato a casa e bevevano vino che condividevano con noi - Favorì! - e che noi bevevamo volentieri. La generosità è stata, e sarà per sempre, spero, la massima virtù del contadino del Meridione. Lospitalità segue a questa e noi abbiamo goduto di entrambe. Fummo i benvenuti nelle case a Bernalda, Montescaglioso, e Pantanello (Casa Torraco). Molto limitati nella capacità di ricambiare il favore, offrivamo una festa alla fine della campagna di scavo, sotto quegli stessi eucalipti. La festa era a base di arrosto di agnello e di capretto, dell'ottimo pane di Montescaglioso, e di quel vino casalingo senza paragone. La festa iniziava all'1:00 del pomeriggio e proseguiva fino a sera con musica e balli. Queste feste ormai sono diventate leggendarie e si ricordano dopo 30 anni.

\section{Gli ospiti italiani}

Fu una grande fortuna incominciare il progetto per invito di Dinu Adamesteanu. Sin dall'inizio l'atmosfera della Soprintendenza è stata sempre incoraggiante e collaborativa e questo continua ancora oggi, malgrado i cambiamenti nell'amministrazione. Sia sul sito a Pantanello, che negli studi degli scavi a Metaponto, o alla sede della Soprintendenza a Potenza, si respirava un'aria di cordialità - dai custodi dei musei e restauratori, agli assistenti e colleghi italiani e stranieri, e allo stesso Soprintendente, Dinu. Eravamo amici e lavoravamo collo stesso obbiettivo. Mi ricordo con particolare gratitudine dell'aiuto costante e dei consigli di Dieter Mertens e Antonio De Siena, i quali condividevano con me la loro conoscenza di prima mano della città antica e mi incoraggiavano a continuare il lavoro nella chora - due aspetti della stessa realtà, per così dire.

Il sito, Pantanello, fu la scelta di Dinu. Nell'autunno del 1973 quando lo vidi per la prima volta, niente era visibile sulla superfice, tranne alcune tegole antiche che indicavano quel che si trovava al di sotto. Questo avrebbe potuto scoraggiare altri, ma noi non eravamo in cerca né di elementi architettonici né di un santuario, sebbene giacessero sotto la superfice. Eravamo tutti eccitati all'idea di scoprire la campagna antica, una nuova frontiera resa reale dalle scoperte di pionieri come Dinu. La campagna di scavo della chora di Metaponto svoltasi a metà degli anni 1960 e lo scavo delle fattorie avevano aperto un nuovo mondo che desideravamo esplorare. Non era un caso che negli anni '70 Pantanello diventasse l'inizio di una estesa ricerca della chora. Essa seguì l'indagine precedente della Soprintendenza, che si era svolta a metà degli anni '60, proseguì e si estese nell'arco di 40 anni. Dinu riusciva a concepire la totalità dell'occupazione dei territori greci e indigeni, ed era aperto ad una varietà di evidenze. Egli rese possibile negli Stati Uniti la mostra dei resultati di quattro anni di ricerca a Pantanello e Incoronata. Lui stesso partecipò ad un simposio, sponsorizzato dalla National Endowment for the Humanities (NEH), intitolato "Ancient Crossroads" che durò un semestre e fu accompagnato da una mostra tenutasi ad Austin nel Humanities Research Center (HRC) e successivamente a musei in quattro altre città: Houston, Corpus Christi, Vancouver, B.C., ed Edmonton nel Canada. In quell'occasione sostenne, presso l'amministrazione della nostra università, la fondazione di un istituto, ICA, che avrebbe continuato a svolgere ricerche sulla colonia greca a Metaponto. Siamo stati molto fortunati che i successori di Dinu, Elena Lattanzi e Antonio De Siena, condividessero il suo entusiasmo e la sua intenzione di promuovere un'atmosfera di collaborazione internazionale. Pantanello si rivelò un ottimo sito per tale scavo, non solo dal punto di vista archeologico, ma anche dal punto di vista amministrativo.

Oltre all'incoraggiamento e al sostegno morale, la Soprintendenza ha dato al progetto di scavo sostegno infrastrutturale, che è stato vitale: spazi dove esaminare, restaurare, e documentare i reperti: all'inizio nella venerabile Casa Teresa (vicino alle Tavole Palatine, il Tempio di Era sul Bradano), in seguito nel Museo Nazionale di Metaponto (1990), e in una struttura aggiunta, il laboratorio conosciuto come "la Banca"luoghi che si trovano a pochi passi dal sito, dalla nostra abitazione a Pantanello, e dal Museo. 


\section{La regione}

Dopo l'esproprio della terra dove la famiglia Lacava allevava buoi a seguito delle riforme agrarie degli anni '50, la terra fu destinata alle sperimentazioni agricole prima dall'Ente Irrigazione di Bari (1962-81), nella persona dell'Ing. Salvatore Dedono, che visitava spesso lo scavo. Nel 1981 la regione Basilicata ne prese le redini. Oltre al centro per la diffusione di nuovi metodi agricoli (CIFDA) e la fattoria sperimentale "Azienda Sperimentale Pantanello," vi si trovava negli anni '80 una banca di plasma germinale associata con il Centro Nazionale di Ricerca (CNR), dove si conservavano, per eventuali ibridizzazioni, i semi di molte coltivazioni vitali provenienti da tutte le parti del mondo. Un centro della conservazione di piante, l'Agrobios di Metaponto, fu stabilito nel 1985, proprio accanto al nostro laboratorio. Un quarto di secolo dopo, sarebbe diventata la nostra biblioteca, il nostro studio, nonché la nostra sala conferenze. Sembrava provvidenziale che sullo stesso posto si trovasse uno scavo archeologico dedicato, almeno in parte, anche al recupero dei resti di piante coltivate nell'antichità su quello stesso luogo - le prove incontestabili della flora e della sua storia che non esiste in nessun altro sito greco-antico del Mediterraneo.

Per quasi 40 anni siamo stati ospiti fortunati della Regione Basilicata, aiutati sia dai consigli e dall'assistenza di Salvatore Martelli, il Direttore dell'Azienza Sperimentale (1981-metà degli anni'90), che dall'amicizia e dell'ospitalità di Leonardo Torraco, Capo Azienda, di sua moglie Antonietta, e dei loro figli, Rocco e Rosetta. La loro casa estiva era una comoda fattoria a due piani, la cui terrazza dà sul sito archeologico del Santuario. Leonardo andò in pensione nel 1999, e in quell'anno, l'Assessorato dell'agricoltura della regione e ICA firmarono una convenzione che creò il Centro di Agroarcheologia. La missione del Centro è quello di continuare a esplorare la storia dell'agricoltura in Basilicata e di trasmettere questa informazione al pubblico e agli studiosi. La squadra dell'ICA avrebbe poi continuato a fare ampio uso non solo dell'edificio che aveva funzionato da spazio di lavoro e da biblioteca, ma anche della casa dei Torraco, che diventò, dopo la sua ristrutturazione nel 1999, l'alloggio dei membri delle squadre di scavo e di studio.

\section{I nostri contributori}

Sin dall'inizio il sostegno di fondazioni e individui è stato un elemento cruciale per il successo del progetto del Santuario a Pantanello, come per tutti i proget- ti dell'ICA. Nei primi anni, l'Università del Texas ha contribuito una limitata quantità di capitale iniziale attraverso il College of Humanities (più tardi conosciuto come College of Liberal Arts, ovvero COLA). In questi ultimi anni COLA, sotto la direzione del Dean Randy Diehl, ha dimostrato di nuovo il suo sostegno ai progetti dell'ICA. I contributi di fondazioni e individui sono stati essenziali per avviare il progetto a Metaponto dopo la prima campagna nel 1974. Era un gruppo fedele nel quale potevo contare dei grandi amici, i cui assegni erano generosi e arrivavano con frequenza. Anno dopo anno, scrivevo loro in primavera prima che la campagna annuale ricominciasse. Alla fine della campagna, prima di partire dall'Italia, scrivevo loro una lettera che mandavo insieme a una dozzina di fotografie. Molti hanno continuato a mandare i loro contributi finanziari per tutta la vita. Alcuni pensavano che, dato che ero nel Texas, non ci mancasse il sostegno finanziario. Invece era un vero lavoro ma un lavoro che mi piaceva, perché questi sostenitori diventarono amici e potevano considerarsi colleghi in un'iniziativa emozionante.

Tra le prime e più fedeli fondazioni ci furono Ben Vaughan attraverso la James R. Dougherty Foundation e Ralph and Maconda O'Connor con la Brown Foundation. Dopo il 1977, questi contributi privati vennero raddoppiati per tre anni grazie alle sovvenzioni della National Endowment for the Humanities, che ha aiutato il progetto a svilupparsi. Gli esperti che dovevano valutare i nostri progetti venivano da diversi campi nell'ambito archeologico, e con il loro incoraggiamento, i nostri progetti si fecero interdisciplinari, fatto che, in pochi anni, ne diventò il segno caratteristico. Gli aspetti più originali dei progetti dell'ICA interesse nella paleobotanica, geologia, archezoologia, e biologia umana - si svilupparono tra il 1977 e il 1985, e coincidono con le importanti scoperte dei materiali organici conservati soprattutto a Pantanello, ma anche in altre parti della chora. Il progetto di Metaponto è un esempio di una collaborazione tra enti privati e pubblici nell'ambito degli studi umanistici. Speriamo che non sia stato l'ultimo.

Nel 1994, feci domanda alla NEH per un'altra sovvenzione triennale per cominciare lo studio dei reperti del Santuario, destinato alla pubblicazione. Le sovvenzioni della NEH per facilitare la pubblicazione dei dati sono state un enorme aiuto, perché è molto più difficile trovare fondi per la pubblicazione che per continuare uno scavo, benché questo sia l'unico modo in cui i ri- 
sultati possono essere diffusi e conosciuti. Nel 1997, il Dr. Packard offrì di aiutarci e, grazie al suo intervento, è stato possibile mettere insieme il gruppo di studiosi e studenti americani ed europei menzionati prima per intraprendere uno. Questa collana di pubblicazioni conta già 13 volumi (sette titoli) e abbiamo raggiunto (ma resta da realizzarsi definitivamente) il nostro obbiettivo di portare Metaponto alla conoscenza di tutti gli studiosi - archeologhi e storici - della Grecia antica. Oltre a rendere disponibili i risultati delle ricerche e delle campagne di scavo, le sovvenzioni del PHI hanno dato a molti studenti e al pubblico la possibilità di comprare i nostri volumi a prezzi ragionevoli.
Per fare progressi in qualsiasi impresa scientifica, è necessario avere il sovvenzionamento adeguato e, nell'archeologia, anche il tempo. David Packard lo capì subito quando mi chiese quanto tempo sarebbe stato necessario. Risposi, "Vent'anni". E così è stato. La NEH aveva avuto una buon'idea, ma purtroppo è un ente che dipende dai politici. L'impegno a lungo termine di David Packard nella ricerca degli studi umanistici è davvero lungimirante. Gli studiosi della Magna Grecia devono al PHI e a David Packard immensa gratitudine ed io gli sono grato per avermi aiutato a realizzare il sogno di una vita. 